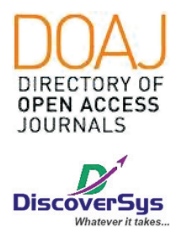

Published by DiscoverSys

\section{Remaja pria 18 tahun dengan hipogonadotropik- hipogonadisme dan postur tubuh pendek: Sebuah laporan kasus}

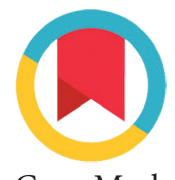

CrossMark

\author{
Metanolia Sukmawati, ${ }^{1 *}$ Antonius Wahyudi, ${ }^{1}$ Judie Hartono, ${ }^{2}$ Tjahjo Djojo Tanojo ${ }^{2}$
}

\title{
ABSTRACT
}

Background: Hypogonadotropic hypogonadism $(\mathrm{HH})$ is congenital or acquired disease affects hypothalamus or pituitary, so the secretion of GnRH, FSH, LH, and testosterone are inadequate. Clinical manifestations both physical and psychological impair patient's quality of life, so authors try to report this case.

Case description: An 18 years old man complained about a small penis. Small penis cause patient had introvert personality and problems in social relations. On anthropometric status, body weight was below $3^{\text {rd }}$ percentile, height was below $3^{\text {rd }}$ percentile, and body mass index (BMI) was thin. The genital examination was $2^{\text {nd }}$-grade tanner, penis with $3 \mathrm{~cm}$ length and $3 \mathrm{~cm}$ circumference, minimal little pubic hair, and testicular volume $<2$ cc. Ultrasound examination showed no presence of testes in the right or left scrotum fossa, inguinal, and lumbar region. Chromosome analysis showed $46 \mathrm{XY}$, and hormones analysis found $\mathrm{FSH}$, LH, and testosterone below the normal limit. The patient was given 2000 unit HCG injection and after that FSH, $\mathrm{LH}$, and testosterone hormone increase compared before HCG injections.

Conclusion: HH can impair physical and psychological patient's quality of life through delays in sexual maturation and bone maturation. Strategies to recognize symptoms in early childhood and puberty induction on time can significantly improve the sexual and reproductive function of $\mathrm{HH}$ patients.

Keywords: hypogonadotropic, hypogonadism, adolescent, micropenis

Cite This Article: Sukmawati, M., Wahyudi, A., Hartono, J., Tanojo, T.D. 2019. Remaja pria 18 tahun dengan hipogonadotropik-hipogonadisme dan postur tubuh pendek: Sebuah laporan kasus. Intisari Sains Medis 10(3): 568-574. DOI: 10.15562/ism.v10i3.465

\section{ABSTRAK}

Latar belakang: Hipogonadotropik hipogonadisme (HH) adalah penyakit kongenital atau acquired yang mempengaruhi hipotalamus atau hipofisis sehingga sekresi GnRH, FSH, LH, dan testosteron menjadi tidak adekuat. $\mathrm{HH}$ merupakan penyakit dengan manifestasi klinis baik fisik maupun psikiologis yang dapat menggangu kualitas hidup pasien sehingga melatar belakangi penulis untuk melaporkan kasus ini.

1Program Pendidikan Dokter Spesialis Andrologi, Fakultas Kedokteran Universitas Airlangga/ RSUD Dr.Soetomo, Surabaya, Indonesia

${ }^{2}$ Departemen Kedokteran Biologi, Fakultas Kedokteran, Universitas Airlangga, Surabaya, Indonesia.

\section{*Korespondensi:}

Metanolia Sukmawati; Program

Pendidikan Dokter Spesialis

Andrologi, Fakultas Kedokteran

Universitas Airlangga/ RSUD

Dr.Soetomo, Surabaya, Indonesia;

metanolia.sukmawati-2015@

fk.unair.ac.id

Diterima: 28-03-2019

Disetujui: 16-08-2019

Diterbitkan: 01-12-2019
Deskripsi kasus: Seorang laki-laki berusia 18 tahun datang dengan keluhan penis kecil. Keluhan tersebut menyebabkan pasien memiliki kepribadian yang tertutup dan memiliki permasalahan dalam hubungan sosial. Pada status antropometri didapatkan berat badan dibawah persentil 3, tinggi badan dibawah persentil 3, dan indeks massa tubuh (IMT) yang kurus. Pada pemeriksaan genitalia didapatkan klasifikasi tanner grade 2, panjang dan lingkar penis sebesar $3 \mathrm{~cm}$, rambut pubis ditemukan sedikit, dan volume testis $<2$ cc. Pemeriksaan USG menunjukkan tidaktampak adanya testis difossa skrotum kanan atau kiri, regio inguinal, dan lumbalis kanan kiri. Analisis kromosom didapatkan hasil 46,XY dan analisis hormon FSH, LH, dan testosteron menunjukkan hasil di bawah batas normal. Pasien diberikan suntikan HCG 2000 unit dan analisis hormon FSH, LH, dan testosteron menunjukkan adanya peningkatan dibandingkan dengan sebelum suntikan HCG.

Kesimpulan: HH dapat menggangu kualitas hidup baik fisik maupun psikiologis pasien melalui keterlambatan maturasi seksual dan maturasi tulang. Strategi untuk mengenali gejala $\mathrm{HH}$ di awal masa kanak-kanak serta induksi pubertas tepat waktu dapat secara signifikan meningkatkan fungsi seksual dan reproduksi pasien $\mathrm{HH}$ secara jangka panjang.
Kata kunci : hipogonatropik, hipogonadisme, remaja, mikropenis

Cite Pasal Ini: Sukmawati, M., Wahyudi, A., Hartono, J., Tanojo, T.D. 2019. Remaja pria 18 tahun dengan hipogonadotropik-hipogonadisme dan postur tubuh pendek: Sebuah laporan kasus. Intisari Sains Medis 10(3): 568-574. D0I: 10.15562/ism.v10i3.465

\section{PENDAHULUAN}

Hipogonadotropik hipogonadisme $(\mathrm{HH})$ merupakan sindrom klinis kegagalan gonad karena adanya defisiensi gonadotrophin releasing hormone $(\mathrm{GnRH})$ pada hipotalamus atau gonadotropin pada pituitari. Membedakan $\mathrm{HH}$ menjadi kongenital dan didapat memiliki implikasi klinis yang sangat penting. Penyebab kongenital umumnya jarang terjadi tetapi cenderung memiliki dampak yang 
lebih signifikan pada fungsi reproduksi karena adanya gangguan perkembangan gonad pada fase awal. Penyebab yang didapat dapat bersifat permanen atau reversible dan membutuhkan pendekatan manajemen yang sangat berbeda, sehingga memerlukan penjelasan akurat tentang patologi yang mendasari. ${ }^{1}$ Pada pasien yang mengalami $\mathrm{HH}$, sekresi GnRH umumnya tidak terjadi atau tidak adekuat. Prevalensi bentuk hipogonadisme ini diperkirakan berkisar antara 1: 10.000 hingga 1: 86.000 orang. ${ }^{2}$

$\mathrm{HH}$ dapat bersifat kongenital atau didapat. $\mathrm{HH}$ kongenital $(\mathrm{CHH})$ dibagi dalam dua kelompok utama tergantung pada adanya indra penciuman yaitu $\mathrm{HH}$ anosmik (sindrom Kallmann) dan $\mathrm{HH}$ normosmik yang terisolasi secara kongenital $(\mathrm{HH}$ idiopatik). Insiden $\mathrm{HH}$ kongenital sekitar 1-10 : 100.000 kelahiran hidup, dengan sekitar 2/3 dan $1 / 3$ kasus timbul dari sindrom Kallmann (KS) dan HH idiopatik (IHH). ${ }^{2}$

IHH ditandai oleh rendahnya tingkat gonadotropin dan hormon seks steroid tanpa adanya kelainan anatomis atau fungsional dari poros hipotalamus-hipofisis-gonad. Mekanisme patogenesis dari IHH melibatkan kegagalan neuron GnRH di hipotalamus untuk berdiferensiasi atau berkembang yang menyebabkan kurangnya sekresi $\mathrm{GnRH}$ atau GnRH pulsatile. ${ }^{2}$

Kegagalan perkembangan karakteristik seksual sekunder oleh karena terlambatnya pubertas merupakan manifestasi klinis utama pada $\mathrm{HH}$ remaja. Pada laki-laki, tanda pertama pubertas merupakan pembesaran testis yang secara normal terjadi pada usia 9-14 tahun. Keterlambatan pubertas sering dikaitkan dengan gangguan psikososial yang cukup besar, seperti harga diri yang rendah, penarikan sosial, kinerja sekolah yang buruk, dan bahkan tingkat yang lebih tinggi seperti menggunakan narkoba. Hal tersebut merupakan problematika pasien $\mathrm{HH}$ karena mayoritas mulai menerima perawatan adekuat pada akhir masa remaja yaitu pada usia rata-rata 18-19 tahun. Pengalaman emosional terjadi karena pasien terjebak dalam keadaan pra-pubertas dan di bawah maskulinisasi sementara rekan mereka mengalami pubertas. Selanjutnya, keadaan genitalia eksternal yang belum matang dapat menghasilkan dampak buruk yang merugikan pada kehidupan seksualitas dan kemampuan untuk membentuk hubungan intim terutama bagi mereka yang memiliki riwayat kriptorkismus atau penis mikro. Akibatnya, ditemukan prevalensi tinggi pria dengan $\mathrm{HH}$ yang menderita gejala depresi kronis ketika dewasa sehingga sering membutuhkan penggunaan antidepresan..$^{1,3}$ Oleh karena itulah pada laporan kasus ini penulis mencoba untuk melaporkan $\mathrm{HH}$ pada remaja pria 18 tahun mengingat manifestasi klinis baik fisik maupun psikiologis yang ditimbulkan oleh $\mathrm{HH}$.

\section{LAPORAN KASUS}

Seorang Laki-laki, 18 tahun, pelajar di pondok pesantren datang ke poliklinik andrologi RS Dr Soetomo dengan keluhan penis kecil. Pasien telah disunat pada tahun 2012 dan merasa penis sedikit besar setelah menjalani proses sunat. Pasien mengatakan pernah mengalami mimpi basah pada usia 14-15 tahun sebanyak satu kali dan mengeluarkan cairan mani sebelum ke pondok pesantren. Pasien sudah memeriksakan kondisinya ke dokter spesialis bedah di Nganjuk dan disarankan untuk berobat ke poli andrologi RS Dr Soetomo Surabaya.

Ibu pasien mengatakan ukuran penis sebesar lidi ketika pasien dilahirkan. Ibu pasien juga mengatakan tidak terdapat gangguan selama kehamilan dan hanya meminum vitamin yang dibeli di toko. Persalinan ditolong oleh dukun bayi dan dibawa ke bidan setelah lahir dengan berat badan lahir sebesar 2,5 kg. Kontrol kehamilan dikatakan dilakukan secara rutin di bidan.

Riwayat penyakit penyerta seperti kelainan jantung kongenital disangkal oleh pasien. Pada keluarga, tidak terdapat riwayat penyakit atau keluhan yang sama dengan pasien. Pasien mampu melakukan motorik kasar seperti berjalan pada usia 1,5 tahun dan bahasa seperti berbicara pada usia 2 tahun.

Pasien memiliki kepribadian yang tertutup dan dikatakan memiliki permasalahan dalam sosial serta pertemanan. Pasien dijauhi dan sering dilecehkan oleh teman-temannya karena memiliki postur badan dan penis yang kecil, serta suara seperti anak-anak.

Pada pemeriksaan fisik status present ditemukan dalam batas normal dimana tekanan darah sebesar 97/65 $\mathrm{mmHg}$, denyut nadi sebesar $72 \mathrm{kali} /$ menit, pernapasan sebesar $20 \mathrm{kali} /$ menit, dan temperatur aksila sebesar $36,5^{\circ} \mathrm{C}$. Pada status antropometri didapatkan berat badan sebesar $39 \mathrm{~kg}$ (dibawah persentil 3 atau gizi buruk), tinggi badan sebesar $145 \mathrm{~cm}$ (dibawah persentil 3 atau perawakan kerdil), indeks massa tubuh (IMT) sebesar $18,54 \mathrm{~kg} / \mathrm{m}^{2}$ (antara persentil 3-10 atau kurus), lingkar perut $70 \mathrm{~cm}$, dan panjang tangan ketika direntangkan sebesar $156 \mathrm{~cm}$ (Gambar 1 dan 2).

Pada pemeriksaan fisik umum didapatkan kemampuan dalam mencium bau dalam batas normal dimana pasien dapat mencium bau namun tidak mengetahui zat yang menimbulkan bau dan tidak ditemukan adanya ginekomastia. Pada pemeriksaan genitalia didapatkan klasifikasi tanner 

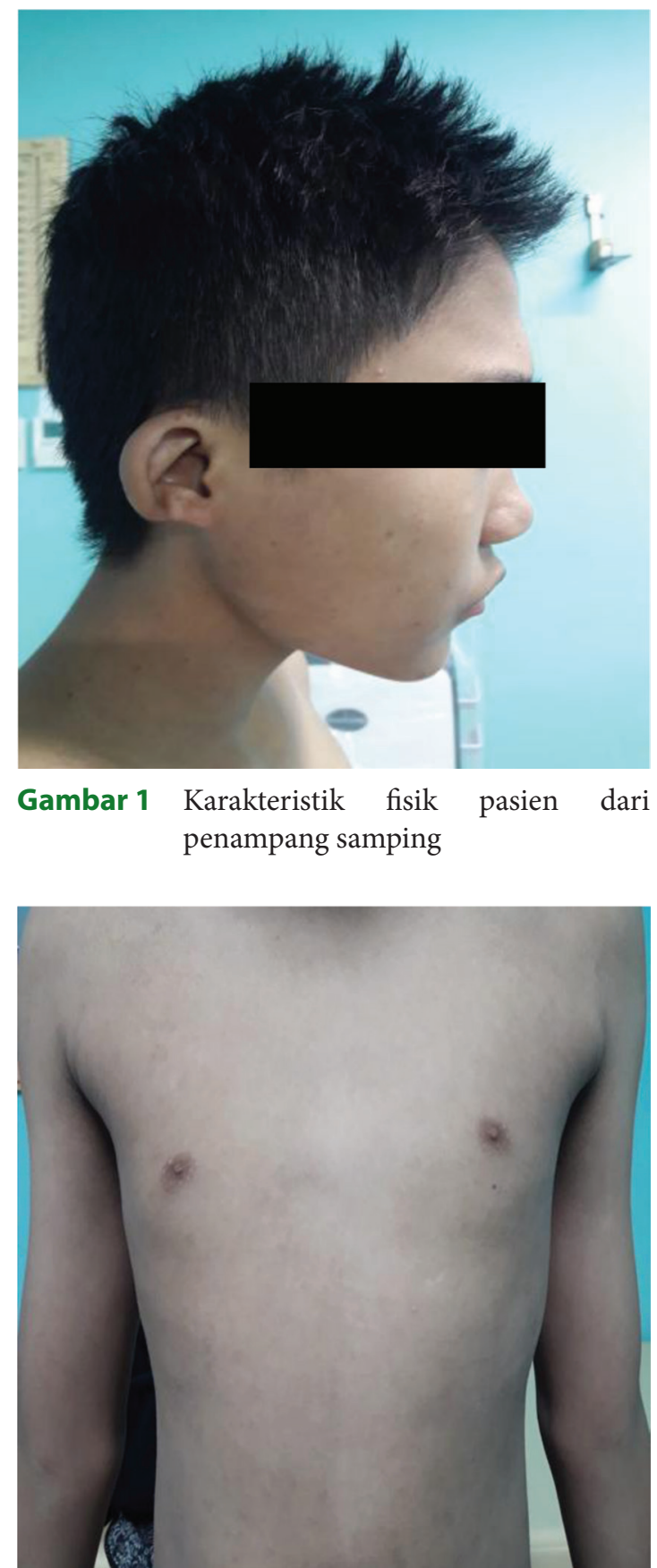

Gambar 2 Karakteristik fenotipe bentuk tubuh pasien dari penampang anterior

grade 2, penis post sirkumsisi dengan panjang penis sebesar $3 \mathrm{~cm}$ dan lingkar penis sebesar $3 \mathrm{~cm}$, serta rambut pubis ditemukan sedikit. Posisi testis di inguinoskrotal bilateral, memiliki volume $<2 \mathrm{cc}$, konsistensi lembek, dan tidak ditemukan adanya nyeri tekan (Gambar 3). Pasien direncanakan untuk melakukan beberapa pemeriksaan penunjang seperti pemeriksaan laboratorium, ultrasonografi (USG), dan analisis kromosom.

Pada tanggal 15 Januari 2019, pasien datang ke poliklinik untuk kontrol dan membawa hasil pemeriksaan penunjang sebelumnya yaitu analisis

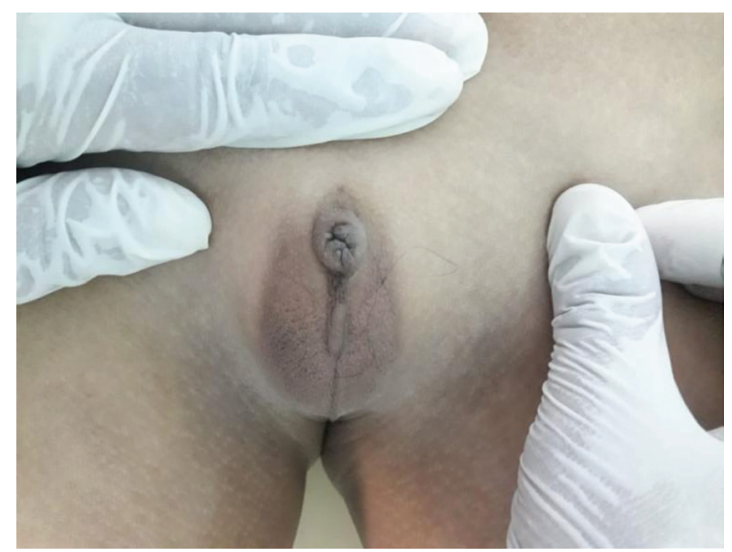

Gambar 3 Penampilan genitalia eksterna pasien dimana menunjukkan panjang penis sebesar $3 \mathrm{~cm}$, lingkar penis sebesar $3 \mathrm{~cm}$, volume testis $<2 \mathrm{cc}$, dan rambut pubis ditemukan sedikit

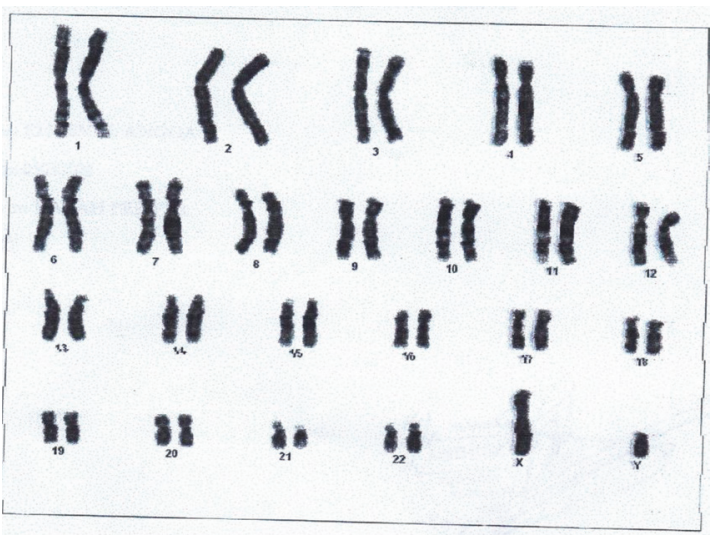

Gambar 4 Hasil analisis kromosom pada tanggal 11 Januari 2019 dengan menggunakan spesimen darah perifer menunjukkan hasil $46, \mathrm{XY}$

hormon FSH, LH, testosteron, USG, dan analisis kromosom. Analisis kromosom dilakukan pada 11 Januari 2019 dengan menggunakan spesimen darah perifer dan didapatkan hasil 46, XY (Gambar 4). Analisis hormon FSH, LH, dan testosteron dilakukan pada tanggal 12 Januari2019 dimana hasil menunjukkan LH sebesar $<0,07 \mathrm{mIu} / \mathrm{ml}$ (nilai rentang normal 1,5-9,3), FSH sebesar $0,39 \mathrm{mIu} / \mathrm{ml}$ (nilai rentang normal 1,4-18,1), dan testosteron sebesar $<7,00 \mathrm{ng} / \mathrm{dl}$ (nilai rentang normal 241-827). Pemeriksaan USG abdomen tanggal 14 Januari 2019 ditemukan tidak tampak gambaran testis di fossa skrotum kanan kiri, regio inguinal, dan lumbalis kanan kiri. Berdasarkan atas hasil keluhan klinis dan pemeriksaan penunjang, maka pasien diputuskan untuk menjalani challenge HCG 2000 unit pada 21 Januari 2019.

Pasien melakukan kontrol kembali pada tanggal 21 Januari 2019 dan pasien dilakukan USG abdomen untuk konfirmasi hasil di poliklinik andrologi 
dimana hasil menunjukkan tidak tampak adanya testis di skrotum, inguinal, atau regio abdomen. Pasien juga menjalani challenge HCG pertama sebesar 9 klik di umbilikus kiri dan direncanakan untuk menjalani pemeriksaan laboratorium kembali pada tanggal 28 Feburari 2019.

Pada tanggal 29 Januari 2019, pasien datang melakukan kontrol dengan membawa hasil pemeriksaan hormon $\mathrm{LH}, \mathrm{FSH}$, dan testosteron pasca administrasi challenge HCG. Hasil analisis LH menunjukkan $0,01 \mathrm{mIu} / \mathrm{ml}$ (nilai rentang normal 1,5-9,3), FSH sebesar $0,47 \mathrm{mIu} / \mathrm{ml}$ (nilai rentang normal 1,4-18,1), dan testosteron sebesar 20,44 ng/dl (nilai rentang normal 241-827).

\section{PEMBAHASAN}

Hipogonadisme pria ditandai oleh gangguan fungsi testis yang dapat mempengaruhi spermatogenesis dan/atau sintesis testosteron. HH pada pria adalah konsekuensi dari penyakit kongenital atau acquired yang mempengaruhi hipotalamus dan/atau kelenjar hipofisis, sehingga sekresi GnRH menjadi tidak adekuat. ${ }^{2,4}$

$\mathrm{CHH}$ berkaitan dengan indra penciuman yang normal terjadi pada $40-45 \%$ kasus yang dikenal dengan normosmic idiopathic central hypogonadism (nICH) atau normosmic hypogonadotropic hypogonadism $(\mathrm{nHH})$ atau IHH. IHH ditandai dengan terlambatnya atau tidak adanya perkembangan seksual dan infertilitas yang terkait dengan kadar gonadotropin ( $\mathrm{LH}$ atau FSH) dan tingkat steroid seks (testosteron atau estradiol) yang rendah tanpa adanya kelainan anatomi atau fungsional sumbu hipotalamus-pituitari-gonad (HPG). Ketika indra penciuman rusak berupa hiposmia atau anosmia maka gangguan tersebut dikaitkan dengan KS yang terjadi pada $60 \%$ pasien. ${ }^{6-8}$

Meskipun laki-laki lebih dominan pada kasus $\mathrm{CHH}$ (4:1), namun masih tidak dapat sepenuhnya dijelaskan pada tingkat genetik karena hanya sebagian kecil kasus yang diidentifikasi sebagai keterkaitan kromosom X. ${ }^{9}$ Gen KAL1 telah dikaitkan dengan KS dan merupakan gen yang berkaitan erat dengan defisiensi GnRH. Mutasi pada gen ini menyebabkan gangguan migrasi $\mathrm{GnRH}$ dan neuron olfaktori. Kegagalan neuron GnRH untuk bermigrasi dari placode olfaktorius menuju tujuan mereka di hipotalamus dan lobus olfaktorius merupakan defek embriologis dasar dari KS. Gen KAL-1 merupakan mode resesif terkait kromosom X.2,10

Karakteristik klinis $\mathrm{HH}$ adalah defisiensi androgen dan kekurangan/ keterlambatan/terhentinya pada maturasi seksual pubertas. Selain itu, HH dianggap idiopatik $(\mathrm{IHH})$ ketika terdapat defisiensi sekresi GnRH terisolasi pada individu di atas
18 tahun. Di bawah usia itu, HH lebih tepat didefinisikan sebagai keterlambatan pubertas. Sulit untuk membedakan antara $\mathrm{HH}$ dan keterlambatan pubertas karena kadar gonadotropin dan testosteron yang rendah ditemukan pada kedua kondisi tersebut. Oleh karena itu, diagnosis $\mathrm{HH}$ definitif harus dikonfirmasi hanya setelah pasien berusia 18 tahun. ${ }^{2,11}$

Penampilan karakteristik klinis tergantung pada onset $\mathrm{HH}$. Ketika defisiensi GnRH terjadi pada akhir fetus atau periode neonatal awal maka insiden kriptorkismus dan/atau penis mikro sangat tinggi. ${ }^{11}$ Laki-laki yang mengalami HH yang dimulai pada fase pra pubertas menunjukkan proporsi tubuh eunuchoid, keterlambatan dalam perkembangan karakteristik seksual sekunder, suara bernada tinggi, testis kecil (biasanya $<6 \mathrm{~cm}^{3}$ ), penis mikro $(<5 \mathrm{~cm})$, rambut pubis yang minimal, maturasi tulang yang tertunda, dan kepadatan mineral tulang rendah. Pria dengan kondisi $\mathrm{HH}$ delayed hadir dengan libido yang berkurang, penambahan berat badan, impotensi seksual, sensasi panas atau gerah, dan infertilitas. Infertilitas merupakan salah satu keluhan paling sering yang dialami oleh pasien dan memiliki efek negatif pada kualitas hidup.,12 Laporan kasus menunjukkan bahwa pasien memiliki berat badan $39 \mathrm{~kg}$ (gizi buruk), tinggi badan sebesar $145 \mathrm{~cm}$ (perawakan kerdil) bila didasarkan pada kurva pertumbuhan CDC sehingga menunjukkan bahwa pasien memiliki permasalahan pada proses pertumbuhan dan perkembangan.

Penis mikro mencakup serangkaian kondisi bawaan atau didapat yang menunjukkan adanya penis pendek abnormal dengan panjang ketika dibentangkan lebih dari 2,5 standar deviasi (SD) di bawah rata-rata untuk usia tertentu dan keberadaan organ genital internal dan eksternal yang kompatibel dengan kariotipe 46,XY meskipun tanpa hipospadia seperti yang ditunjukkan oleh morfologi meatus uretra normal pada ujung penis. ${ }^{13}$ Penis mikro umumnya dikaitkan dengan defisiensi testosteron sejak usia kehamilan 12 minggu dimana testosteron diinduksi oleh GnRH selama organogenesis. Pada kasus diatas didapatkan bahwa ukuran panjang penis pasien ketika dibentangkan sebesar $3 \mathrm{~cm}$ dan berada 2,5 SD dibawah rata-rata ukuran penis pada dewasa $(7,2 \mathrm{~cm}) .{ }^{2,4}$ Pasien dengan penis mikro juga memiliki permasalahan sosial karena sering tidak merasa puas dengan kualitas kehidupan seksual, penampilan kosmetik, atau stigmatisasi pada masyarakat. Hal ini sejalan dengan laporan kasus dimana pasien memiliki kepribadian tertutup dan dijauhi oleh teman-teman karena memiliki postur badan dan penis yang kecil serta suara seperti anak-anak.

Di antara pasien dengan hipogonadotropik hipogonadisme, defisiensi fungsional lebih sering 
dikaitkan dengan hormon lutein janin dibandingkan dengan gangguan diferensiasi seksual. Penyebab yang kurang sering termasuk defisiensi hormon pertumbuhan dan kelainan fungsional idiopatik dari aksis hipotalamus-pituitari-testis. ${ }^{9}$

Setiap diagnosis hipogonad harus dimulai dengan konfirmasi kadar testosteron dalam darah dimana kadar testosteron bebas lebih disukai karena berdasarkan pada total tingkat testosteron, tingkat albumin, dan tingkat sexual hormone binding globulin (SHBG). Tes laboratorium ini sebaiknya dilakukan sebelum jam 10 pagi karena berkaitan dengan ritme sirkadian hormon pria. Jika kadar testosteron rendah, maka analisis selanjutnya harus dilakukan yaitu analisis kadar gonadotropin (FSH dan LH). Tingkat hormon hipofisis yang rendah mengkonfirmasi diagnosis $\mathrm{HH}^{2}{ }^{2}$

Penilaian endokrinologis membantu menentukan apakah tingkat penyebab penis mikro adalah pada poros hipotalamus-hipofisis-testis. Selain evaluasi fungsi endokrin sentral, fungsi testis juga perlu dievaluasi secara bersama-sama. Oleh karena itu, kadar testosteron serum diukur sebelum atau setelah pemberian hCG. Tes ini dilakukan dengan pemberian hCG intramuskular dalam dosis 1.000 unit setiap 3 hari atau 1.500 unit setiap dua hari selama 14 hari dimana kadar testosteron di bawah $300 \mathrm{ng} / \mathrm{dL}$ dapat mengindikasikan disgenesis gonad. Jika kadar LH dan FSH meningkat, namun tidak ada peningkatan kadar testosteron setelah administrasi maka insufisiensi atau ketidakhadiran testis harus dipertimbangkan. ${ }^{13}$ Pasien pada laporan kasus diatas diadministrasikan challenge HCG sebesar 2000 unit dan dilakukan analisis FSH, LH, dan testosteron baik sebelum dan setelah administrasi HCG. Analisis hormon FSH, LH, dan testosteron menunjukkan adanya peningkatan dibandingkan dengan sebelum suntikan HCG meskipun hasil masih berada dibawah rentang nilai normal.

Analisis hormon GnRH secara langsung sangat sulit untuk dilakukan karena GnRH terbatas dalam sistem portal hipofisis dan menunjukkan waktu paruh yang singkat yaitu 2 hingga 4 menit. Oleh karena itu, tingkat GnRH lebih baik diperiksa melalui cara yang tidak langsung melalui absennya LH pulsatil baik bersifat total atau sebagian, regulasi fungsi hipofisis dan gonad, dan respon terhadap penggantian GnRH eksogen yang mampu memeriksa integritas mekanisme kontrol sistem hipotalamus-hipofisis. Tes GnRH intravena yang distimulasi secara berkepanjangan dengan dosis 100 mcg dan diikuti oleh 500 mcg dapat bermanfaat pada defisiensi GnRH hipotalamus dimana LH dan FSH secara bertahap muncul. ${ }^{2}$
Magnetic resonance imaging (MRI) dari daerah hipotalamus dan hipofisis sangat berguna dalam pengelolaan $\mathrm{CHH}$ karena MRI dapat menunjukkan malformasi atau tumor. Pada sindrom Kallmann, MRI otak dapat menunjukkan morfologi anomali atau tidak adanya bulbus olfaktori dan karena itu memainkan peran penting dalam diagnosis presumtif. ${ }^{2}$ Studi genetik biasanya merupakan langkah terakhir dalam investigasi $\mathrm{CHH}$ dan manifestasi klinis lengkap bisa sangat berguna dalam pemilihan gen yang akan diskrining. ${ }^{13}$

Beberapa studi menunjukkan bahwa pemeriksaan kariotipe dengan menggunakan analisis kromosom atau Y-fluorescence cukup berfungsi dalam menentukan jenis kelamin. Tes genetik juga dapat bersifat penting untuk mengeliminasi sindrom lainnya. ${ }^{13}$ Penilaian klinis yang cermat sehubungan dengan evaluasi biokimia seperti darah lengkap, profil ginjal dan hati, penanda inflamasi, fungsi tiroid, dan zat besi sangat penting untuk menyingkirkan gangguan kronis yang mendasari gangguan pertumbuhan dan perkembangan. Berbagai tes fisiologis dan stimulasi telah diajukan selama bertahun-tahun dimana beberapa hasil yang menjanjikan muncul dari penelitian terbaru tentang serum inhibin $\mathrm{B}$, tetapi belum ada pemeriksaan baku emas dalam mendiagnosis $\mathrm{HH}{ }^{1}$

Rencana dan tujuan terapi pada pasien remaja dengan hipogonad hipogonadotropik adalah induksi pubertas sesuai dengan usia dan mengoptimalkan pertumbuhan sehingga mampu dalam menghindari komplikasi psikososial. Tujuan terapi lainnya adalah untuk memperbaiki body image sehingga tidak menyebabkan rasa malu bagi pasien dan agar pasien memiliki fungsi seksual yang normal. ${ }^{13}$

Tingkat androgen yang normal dan perkembangan karakteristik seks sekunder dapat dicapai dengan penggantian androgen secara tunggal. Namun, terapi GnRH atau gonadotropin adalah pilihan terbaik bagi pria yang ingin memiliki anak karena stimulasi produksi sperma memerlukan pengobatan human chorionic gonadotropin (hCG) tunggal atau dikombinasikan dengan FSH rekombinan, FSH urin, atau human menopausal gonadotropin (hMG). ${ }^{2}$

Rantai $\beta$ LH dan hCG sangat mirip dan menunjukkan sifat yang sama seperti afinitas untuk reseptor pada sel Leydig. Saat ini gonadotropin urin menjalani proses purifikasi yang tinggi dan dapat disuntikkan secara subkutan sehingga mampu menghindari induksi antibodi. ${ }^{2}$

Perawatan gonadotropik dimulai dengan pemberian 1.000 hingga 2.500 IU hCG dua kali seminggu selama 8 hingga 12 minggu. Fase awal 
ini adalah fase induksi yang sangat penting agar kadar testosteron meningkat. Dalam kasus-kasus tertentu, hCG tunggal dapat menginduksi sperma. Pada individu yang tidak memiliki FSH endogen yang cukup, maka pengobatan dapat dilanjutkan dengan pemberian 75 hingga 150 IU hMG tiga kali seminggu hingga 18 bulan karena keberadaan FSH sangat penting untuk merangsang spermatogenesis. FSH rekombinan dapat digunakan sebagai pengganti hMG dimana pasien menerima 150 IU tiga kali per minggu untuk periode waktu yang sama. Pengobatan kombinasi ini memberikan pertumbuhan testis yang cukup besar pada sebagian besar pasien selain spermatogenesis pada hingga 90\% pasien. Perawatan ini menuntut disiplin dan ketekunan karena durasi yang cukup lama. Dukungan finansial juga diperlukan karena obat yang digunakan cukup mahal. ${ }^{2}$

Terapi hCG secara tradisional digunakan pada pria hipogonad yang menginginkan kesuburan karena dapat berbagi reseptor dengan $\mathrm{LH}$ dan menghasilkan efek yang hampir sama. Dosis biasanya dititrasi hingga konsentrasi serum testosteron dalam kisaran normal. Setelah 6 bulan terapi, konsentrasi sperma dinilai dan jika tidak ada respon yang adekuat maka terapi FSH baik hMG atau FSH rekombinan (rhFSH) dapat ditambahkan pada pasien. Waktu respon dapat berlangsung selama 1-2 tahun untuk terapi kombinasi dan keberhasilan lebih tinggi terjadi pada pria dengan volume testis $>8 \mathrm{cc}$ dan onset lambat hipogonad. Studi juga telah melihat peran terapi hCG dalam pengobatan hipogonadisme pada pria tanpa masalah kesuburan dimana telah terbukti memperbaiki atau meningkatkan gejala hipogonad dan memiliki efek yang menguntungkan pada komposisi tubuh (peningkatan massa lemak bebas dan menurunkan massa lemak), profil lipid (kolesterol total yang lebih rendah, LDL, dan trigliserida yang rendah), dan pembentukan tulang. Terapi hCG juga tampaknya memiliki probabilitas yang lebih kecil untuk menyebabkan efek samping yang buruk dibandingkan dengan administrasi testosteron seperti permasalahan prostat, hematokrit, sleep apnea, dan ginekomastia namun injeksi hCG harus diadministrasikan lebih sering (2-3 kali seminggu). ${ }^{14}$

Pasien dapat dilakukan pemantauan pemeriksaan volume testis serial, hormon T, FSH, dan LH. MRI pituitari tidak dibutuhkan pada saat analisis pertama. Namun, jika tidak adanya pubertas dengan gonadotropin endogen dependen yang persisten (kurangnya pembesaran testis pada serial tindak lanjut) maka diindikasikan MRI otak dengan analisis bulbus olfaktori. Selain menyingkirkan patologi hipotalamus-hipofisis, temuan radiologis absennya bulbus olfaktori hipoplastik bersifat patognomonik untuk sindrom Kallmann. ${ }^{1}$
Secara klasik, durasi perawatan gonadotropin untuk memulihkan spermatogenesis lebih dari tiga bulan. Studi lain memperkirakan durasi spermatogenesis (dari diferensiasi spermatogonia hingga ejakulasi spermatozoa dewasa) membutuhkan waktu sekitar 64 hari. Dalam sebuah studi, pria yang memiliki konsentrasi sperma normal diberikan perlakuan konsumsi air deuterisasi berat $\left(2 \mathrm{H}_{2} \mathrm{O}\right)$ setiap hari dan memberikan sampel cairan sperma setiap dua minggu selama 90 hari. Penggabungan label $2 \mathrm{H}_{2} \mathrm{O}$ ke dalam DNA sperma dikuantifikasi dengan kromatografi gas atau spektrometri massa yang memungkinkan persentase sel baru untuk dihitung. Waktu keseluruhan rata-rata untuk pendeteksian sperma pada ejakulasi adalah $64+8$ hari (kisaran 42-76 hari). Pada pria normal, sperma yang dilepaskan dari epitel seminiferus memasuki epididimis secara terkoordinasi dengan sedikit pencampuran sperma lama dan baru sebelum ejakulasi berikutnya. ${ }^{2}$

\section{SIMPULAN}

$\mathrm{HH}$ adalah suatu kondisi yang bersifat heterogen secara klinis dan seringkali sulit untuk didiagnosis dan dibedakan dengan keterlambatan pertumbuhan selama masa remaja. Kehadiran anosmia dan/atau hipoplasia olfaktorius yang divisualisasikan oleh MRI menunjukkan adanya sindrom Kallmann. Strategi untuk mengenali gejala pada pasien $\mathrm{HH}$ di awal masa kanak-kanak serta induksi pubertas tepat waktu pada masa remaja dapat secara signifikan meningkatkan fungsi seksual dan reproduksi pasien $\mathrm{HH}$ secara jangka panjang. Selain itu, induksi kesuburan melalui terapi hormonal sangat menjanjikan dalam meningkatkan spermatogenesis untuk individu dengan $\mathrm{HH}$.

\section{KONFLIK KEPENTINGAN}

Penulis menyatakan bahwa tidak terdapat konflik kepentingan dalam penilisan artikel ini

\section{PENDANAAN}

Seluruh penulis bertanggung jawab secara mandiri dalam pendanaan laporan kasus ini tanpa melibatkan pihak sponsor atau sumber pendanaan lainnya.

\section{KONTRIBUSI PENULIS}

MS berperan dalam penyusunan laporan kasus, penatalaksanaan farmakoterapi pasien, maupun follow-up pemeriksaan terhadap pasien. Sedangkan $\mathrm{AW}, \mathrm{JH}$, dan TDT berperan sebagai pembimbing dalam pengerjaan laporan kasus ini. 


\section{DAFTAR PUSTAKA}

1. Swee DS, Quinton R.. Managing congenital hypogonadotrophic hypogonadism: a contemporary approach directed at optimizing fertility and long-term outcomes in males. Ther Adv Endocrinol Metab. 2019;10: 1-15.

2. Fraietta R, Daniel SZ, Sandro CE. Hypogonadotropic hypogonadism revisited. Clinics 2013; 68(Suppl 1):81-88.

3. Tsang S. When size matters: a clinical review of pathological micropenis. J Pediatr Health Care. 2010;24(4):231-240.

4. Boehm U, Bouloux PM, Dattani MT, de Roux N, Dodé C, Dunkel L, et al. European consensus statement on congenital hypogonadotropic hypogonadism pathogenesis, diagnosis and treatment. Nat Rev Endocrinol. 2015;11(9):547-564.

5. Shiraishi K, Oka S, Matsuyama H. Assessment of quality of life during gonadotrophin treatment for male hypogonadotrophic hypogonadism. Clin Endocrinol (Oxf). 2014;81(2):259-265.

6. Beate K, Joseph N, Nicolas de R, Wolfram K. Genetics of isolated hypogonadotropic hypogonadism: role of $\mathrm{GnRH}$ Receptor and other genes. Int J Endocrinol. 2012; 2012:1-9.

7. Marino $M$, Moriondo V, Vighi E, Pignatti E, Simoni M. Central hypogonadotropic hypogonadism: genetic complexity of a complex disease. Int J Endocrinol. 2014;2014:1-13

8. Bianco SD, Kaiser UB. The genetic and molecular basis of idiopathic hypogonadotropic hypogonadism. Nat Rev Endocrinol. 2009;5(10):569-576.
9. Oh JK, Im YJ, Park K, Paick JS. Effects of combined growth hormone and testosterone treatments in a rat model of micropenis. Endocr Connect. 2018;7(11):1150-1157.

10. Maione L, Dwyer AA, Francou B, Guiochon-Mantel A, Binart N, Bouligand J, et al. Genetic counseling for congenital hypogonadotropic hypogonadism and Kallmann syndrome: new challenges in the era of oligogenism and next generation sequencing. Eur J Endocrinol. 2018;178(3):R55-R80.

11. Han TS, Bouloux PM. What is the optimal therapy for young males with hypogonadotropic hypogonadism? Clin Endocrinol (Oxf). 2010;72(6):731-737.

12. Wiygul J, Lane SP. Micropenis. Scientific World Journal 2011;11:1462-1469.

13. Hatipoğlu N, Kurtoğlu S. Micropenis: etiology, diagnosis and treatment approaches. J Clin Res Pediatr Endocrinol. 2013;5(4):217-223.

14. Thirumalai A, Berkseth KE, Amory JK. Treatment of hypogonadism: current and future therapies. F1000 research. 2017;6:68.

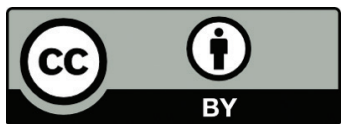

This work is licensed under a Creative Commons Attribution 